\title{
INNOVATIVE COMPETENCE OF A TEACHER: BEST EUROPEAN PRACTICES
}

\author{
OLENA BUDNYK
}

\begin{abstract}
The essence of the innovative competence of the teacher in the way of integration into the world space of education. The main tendencies of teacher's training for professional innovation activity are described. Best European practices according to the using of innovative studying technologies in the work with students are examined. The author proves the need for partner collaboration, group forms of activities to solve problematic learning problems at school through Problem Based Learning. Especially, the issues of development of creative initiative of children in collective work are highlighted. The content and typical difficulties in the practical using of Blended Learning are described. It is noted that Blended Learning combines traditional and distant models of studying, it can take place not only in the lecture room but outside, in synchronous or asynchronous regimes, and it predicts an extensive using of ICT in work with students. The technology of Inquiry Based Learning in teaching STEAM school subjects is presented, especially in the process of working with remote educational laboratories and Inquiry Learning Space (ILS). Some innovative tools for their practical using according to the work with students are implemented. The importance of using Project Based Learning for integration of educational subjects in the New Ukrainian School is also characterized, which gives an opportunity to form a coherent picture of the world in them.
\end{abstract}

Keywords: teacher's innovative competence, educational process, pedagogical activity, Problem Based Learning, Blended Learning, Project Based Learning, Inquiry Based Learning.

\section{INTRODUCTION}

In the conditions of a rapid development of the information society, the reformation of education of different countries in the context of integration into the world, it is important to provide an innovative character of pedagogical activity, which has an important place in the development and selfdevelopment of a young generation. Therefore, the problem of formation and development of innovative competence of the teacher today is very actual.

The problems of teacher's pedagogical competence are highlighted in scientific research by H. Vasianovych, O. Dubaseniuk, I. Ziaziun, L. Karpova, N. Kuzmina, L. Pukhovska, O. Savchenko and others.The methodological approaches to the studying of the teacher's innovative competence are defined in the works of I. Havrysh, I. Dychkivska, O. Ignatovych, N. Klokar, O. Podimova, O. Shafran and others. 
The innovative competence of the teacher is examining by Ukrainian researchers as a component of general professional and pedagogical competence, the content of which is determined by the peculiarities of innovation activity, its social significance, creative character and the focus on the nonstop creation of a new, the development of the personal and professional potential of the teacher [21].

Let's consider the essence of innovative competence of the teacher in the context of our research. So, according to the point of view of I. Dychkivska, she interprets innovative competence through the system of motives, knowledge, skills, skills, personal qualities of the teacher, which ensure the effectiveness of the using of new pedagogical technologies the professional work [9].

Innovative competence of a teacher is "a system of motives, knowledge, abilities, skills, personal qualities of the teacher, which ensures implementation of all stages of innovative professional activity: from modeling and forecasting to introduction of innovations" [20].

In the pedagogical science, the following characteristics of a teacher training according to the innovation activity are determined $[4 ; 12 ; 20]$ :

1. Focus on a teacher training according to the solving the problems of modernizing the education system in accordance with civilization and national strategies for its development respectively on the principles of formative and civilizational approaches in pedagogical education. The essence of the first approach is to take into consideration economic, political and socio-cultural determinants as the system-forming factors of all processes taking place in the educational sphere. Accordingly, a civilizational approach according to the implementation of innovation activities involves the adoption of the idea of the diversity of the world as the formation of individuality in the space of universality to recognize the priority of universal values. At the same time, the world educational systems should function according to the civilization trends of the development of national educational systems.

2. The effeciency of teacher training for innovation activity is determined by the completeness of the implementation of its content, functional and structural links with other components of this training. Therefore, this principle corresponds to the principle of organic unity of general, special and individual in the pedagogical professional activities.

3. The degree of accordance of the teacher's readiness for innovation activity by the objective regularities of professional training. Actually, these regularities correspond to the principles of personal and active approach, in particular: humanism; tolerance; cooperation and co-creation; pedagogical optimism; differentiation and individualization; optimizing the educational process, etc.

4. Degree of accordance of professional preparation of structure and content of innovative professional activity of the teacher. It is primarily about the integrity of this process, and the content of education, according to V. Krayevskiy, is not limited to the assimilation of the foundations of science, the development of the intellectual sphere of the student. The true educated person is able not only to act in the social structure, but also to change it actively [17, p. 6]. In today's university education, the problem of improving content is taken into account, axiological dimensions and practice requirements are taken into consideration, since "the universal knowledge of narrow disciplinary orientation" [24, p. 105] often become unsuitable for using by future specialists because of their inconsistency in the development of scientific and technological progress. An ambivalent situation arises when higher pedagogical education acts as an institution, which is located "on the border between knowledge preserved in libraries and abstracts and computers of teachers, and knowledge that operate in the field of production" [16, p. 21]. Therefore, the rapid socio-cultural, information development of society requires from the teacher of modern knowledge. However, the content of teaching of education needs constant new knowledge, taking into account the principle of scientific knowledge, in connection with life.

Thus, in today's conditions, it is worth emphasizing on the organization of teacher training for innovation based on the principles of the inter-scientific approach, so some basic provisions of the philosophy of education, general innovation, the complex of the sciences of creativity, general psychology, general axiology, pedagogical management, etc., concerning problems of pedagogy innovations [20]. 


\section{ANALYSIS AND DISCUSSION}

With the development of digital society in the pedagogical science the newest educational technologies are increasingly resorted in the practical sphere: Distance Learning, e-Learning, $u-$ Learning, m-Learning, Flipped Learning, methods of interactive learning, learning on technology training, using of short videos (Microlearning), Problem Based Learning, Inquiry Based Learning, etc.

In the modern conditions, the issue of diversifying of teaching methods for STEAM subjects, first of all in middle school classrooms, is also relevant. That is why it is important to prepare teachers to integrate math, science, and technology in the teaching process. The American scientists recommend using 3D printing in authentic design projects for this. "... Students are able to tinker in a virtual world using 3D design software and then in the real world using printed parts" [7].

Actually, the innovative competence of a modern educator is seen in his ability to use the best European educational technologies in professional practice. Dynamic changes in education in the conditions of its integration into the world educational space puts new challenges to teachers - to be prepared for the effective performance of their professional functions, taking into account innovation.

\subsection{Problem BASED LEARNiNG: PEDAgogicAl CREATIVITY}

In the context of the problem of the synthesis of science and art in the STEM-education, we have a tendency for the rapid development of creativity, which includes artistic and creative trends (architecture, industrial design, industrial aesthetics, etc.). Therefore, in the field of STEM, which serves as the basis for the training specialists for high technologies, the development of students' creativity and the representation of Arts-disciplines in the content of their preparation is defined as a strategic point. Its evidence is for example the fact that in the state of Massachusetts (MA, USA) Public Schools for Developing an Index of Creative and Innovative Education are conducting the rating. Today it is extremely important in the behaviour of pupils to use the analytical, creative skills in solving the problem in the field of science, mathematics, reading and writing (students apply analytical, creative, and problem-solving skills in science, mathematics, reading, and writing), the development of innovative talent to meet the needs of its business community [18].

In the researches of scientists (A. M. Connor, S. Karmokar, Ch. Whittington; 2015) the minds about the need to integrate STEM disciplines and arts into a broader educational context (STEAM). After all, natural sciences, technology, engineering, art, mathematics as a system of education involves mastering primarily technological competencies and is aimed at the development of scientific and technical creativity of students. Though technological trends cannot be developed today without such skills as teamwork, creativity, global awareness, financial literacy, aesthetic awareness, critical thinking and etc.

A. Armitage, O. Pihl, T. Ryberg (2015) are examining theoretical, philosophical, pedagogical and aesthetical aspects of the contradictions and interactions between the collective and the individual in creative learning processes. However, today, it is important to develop a student's creative individuality, creativity in the practical activities. At the same time, we involve him in collective, partner interaction, work in groups for the searching of solutions to common painful problems in the process of Problem Based Learning. The authors enforce to the discussion: "In the design process there are always many ways and solutions to solve the same problem, so how can we be sure that we choose the right concept to finding the optimum solution to practical problems? What is the role of PBL in this context?" [1]. It is obviously, that for searching of individual creative perspectives educational strategies adequate to specific goals are necessary. Actually, the aesthetic aspect of teaching involves the formation of an educational environment, which would stimulate students to constructive, collaborative and contextual learning and self-improvement; the combination of individual and collective aspects in the solving of difficult situations.

\subsection{BLENDED LEARNING IN THE WORK OF THE SCHOOL TEACHER}

In many European and American schools of general education, the issue of implementing Blended Learning, which combines the traditional distance learning system, is very important today. According 
to C.R. Graham, a model of Blended Learning, includes traditional and computational learning of students [11].

The definition of blended learning is a formal education program in which a student learns: (1) at least in part through online learning, with some element of student control over time, place, path, or pace; (2) at least in part in a supervised brick-and-mortar location away from home; 3) and the modalities along each student's learning path within a course or subject are connected to provide an integrated learning experience [2].

Blended Learning is a purposeful systemic process of interaction between subjects of learning, in which the traditional and distant learning models are organically combined, mixed learning can take place in the audience and beyond, in synchronous or asynchronous regimes, and involves the wide using of ICT in the work with students. Scientists distinguish the following types of Distance Learning: Traditional Distance Learning (interaction between subjects of learning is taking place with the delay of time (asynchronously), and e-Distance Learning (interaction between participants occurs both asynchronously and synchronously in time, and is based on the using of modern ICTs ) [3, pp. 191-193].

Means of Blended Learning: traditional - textbook, manual, laboratory equipment, technical means of training, etc.; computer support - electronic tutorials, video materials, software for qualitative control of education, information retrieval systems, research training environments, virtual training laboratories, animations and simulations, etc. [6].

In the preparation of a modern teacher, the universities in most cases use mixed learning at the level of individual disciplines by managing learning with the help of appropriate systems (MOODLE, Sakai, Canvas, etc.). For the implementation of the innovative model of Blended Learning in high school, models often are offered by K. Kristens (Blended Learning. Retrieved from http: // goo. gl/AL31PN) are often used. Rotation Model is a turn-based interaction between a teacher and a student with the help of ICT. Flexible model is where the basis of the educational process is distance learning. Self-Blend Model or A La Carte Model - through which the traditional students' trainings can be complemented by additional online courses through the Internet. Enriched Virtual Model is the one characterized by self-learning of students of a part of the educational material with the help of electronic courses.

The typical combination and using of both electronic and traditional training without proper technical support, the availability of the developed pedagogical tools and software does not guarantee the high efficiency of the mixed learning methodology. In this regard, the scientists of Vasyl Stefanyk, the Precarpathian National University, have started active work in the framework of the EU program Erasmus + KA2 - Capacity building in higher education with the project "Modernization of Pedagogical Higher Education by Innovative Teaching Instruments (MoPED)" - No. 586098-EPP-12017 -1-UA-EPPKA2-CBHE-JP, which will last for 3 years (2017-2020).

The main aim of this project is the modernization of the curriculum of higher educational establishments of Ukraine by the implementation of modern teaching methods using ICT. The project is aimed at improving the quality of higher pedagogical education, the development of the digital and didactic competences of future teachers in the context of reforming the educational system, especially the using of innovative teaching methods / tuition (Distance Learning, e-Learning, Mobile Learning, methods of Critical Thinking Development, Interactive Training, etc.).

The peculiarities of the mixed learning model are that materials for studying are submitted to the student electronically; there is also the opportunity to hand over work electronically; systematic evaluation of work with relevant comments is carried out; opportunities for organizing group work are expanding; electronic tracking progress tools are used; full-time learning is based on a person-centered approach, the principle of interactivity, and so on.

In the modern conditions, there are some difficulties according to the introduction of Blended Learning, which J. Hofmann (2011) distinguishes:

technical (Technology challenges): the providing of the learning process with the appropriate technical means; 
organizational (Organizational challenges): overcoming the stereotypical beliefs and convictions about the ineffectiveness of mixed learning, in contrast with the traditional, permanent monitoring of student success and learning management;

teaching (Instructional / design challenges): the presence of an educational environment for achieving the goal; the introduction of online interactive exercises, providing of proper coordination of the mastering of the elements of the course, the sequence of its study, etc. [14].

These problems are also typical for modern school. The main problem is the equipment in the educational process especially innovative computer technologies and development of appropriate training for e-learning, in peculiar, research environments, laboratories, games, surveys and testing systems using smart phones and tablets, interactive tasks, tools for teamwork, recommendations for work in a cloud-based learning environment, etc. In fact, these issues are extremely relevant for different countries, especially in the New Ukrainian school.

\subsection{INQUIRY BASED LEARNING IN THE TEACHING OF SCHOOL STEAM SUBJECTS}

Today, there is a problem in the training of specialists for the use of information technologies in teaching STEM subjects for elementary and secondary schools (Natural Sciences, Mathematics, Science, Technology), because of such online courses require hands-on activities, laboratory works and live demonstrations. Training of the teacher to familiarize the pupils with scientific and engineering fields, IT technologies and others and it involves the mastering of new concepts such as STEM- \& STEAMeducation, STEAM literacy, engineering, reengineering, nanotechnology, robotics, online environment, e-learning, m-learning, u-learning, f-learning, blended-learning, creative industry, mechatronics, fundraising, online discussion forum, digital literacy, information culture and others [5, p. 25].

Early involvement of children in STEAM serves not only as a means of developing creative thinking, forming the competence of the researcher, but also contributes to their socialization, helping them choose their future profession. Interactive studying develops such skills as: collaboration, communication, teamwork, creativity. For the development of gifted children, starting with preschool and junior school age, it is advisable to use STEAM's online learning environment to build skills in design, cooperation, communication and critical thinking based on a multidisciplinary approach $[5$, p. 25].

Today for e-learning you can take advantage of the extensive collection of online labs, interactive inquiry, combine labs and apps into Inquiry Learning Spaces (ILS), etc. (http://www.golabz.eu/). ILS are personalized learning resources for students, where they can conduct scientific experiments, get new knowledge by themselves, and develop research skills. Unfortunately, on this platform, most ILSs are English (232), Portuguese (107), Greek (107) and other languages. At the same time, the GoLab platform is moving in the direction to Eastern Europe. We have the places of a research training in Romanian language - 98, in Ukrainian language - 13, in Polish - 6, in Czech - 2, in Hungarian - 1, in Slovak -0 .

Let's look at some of the online learning space.

ILS "Humans and Bees" (Subject Domains: Biology, Chemistry, Environmental Education, Geography and Earth Science) for students 7-16 years old. In this ILS student's will reflect about the relationship between humans and bees and research the possible human factors that affect bees in a positive and in a negative way. Students will use an online simulator that allows for the variation of bee numbers, flower numbers and their relationship. Furthermore, students will learn about the scientific method and the most important things to have in mind when making a scientific research (https://www.golabz.eu/ils/humans-and-bees) (Fig. 1). 


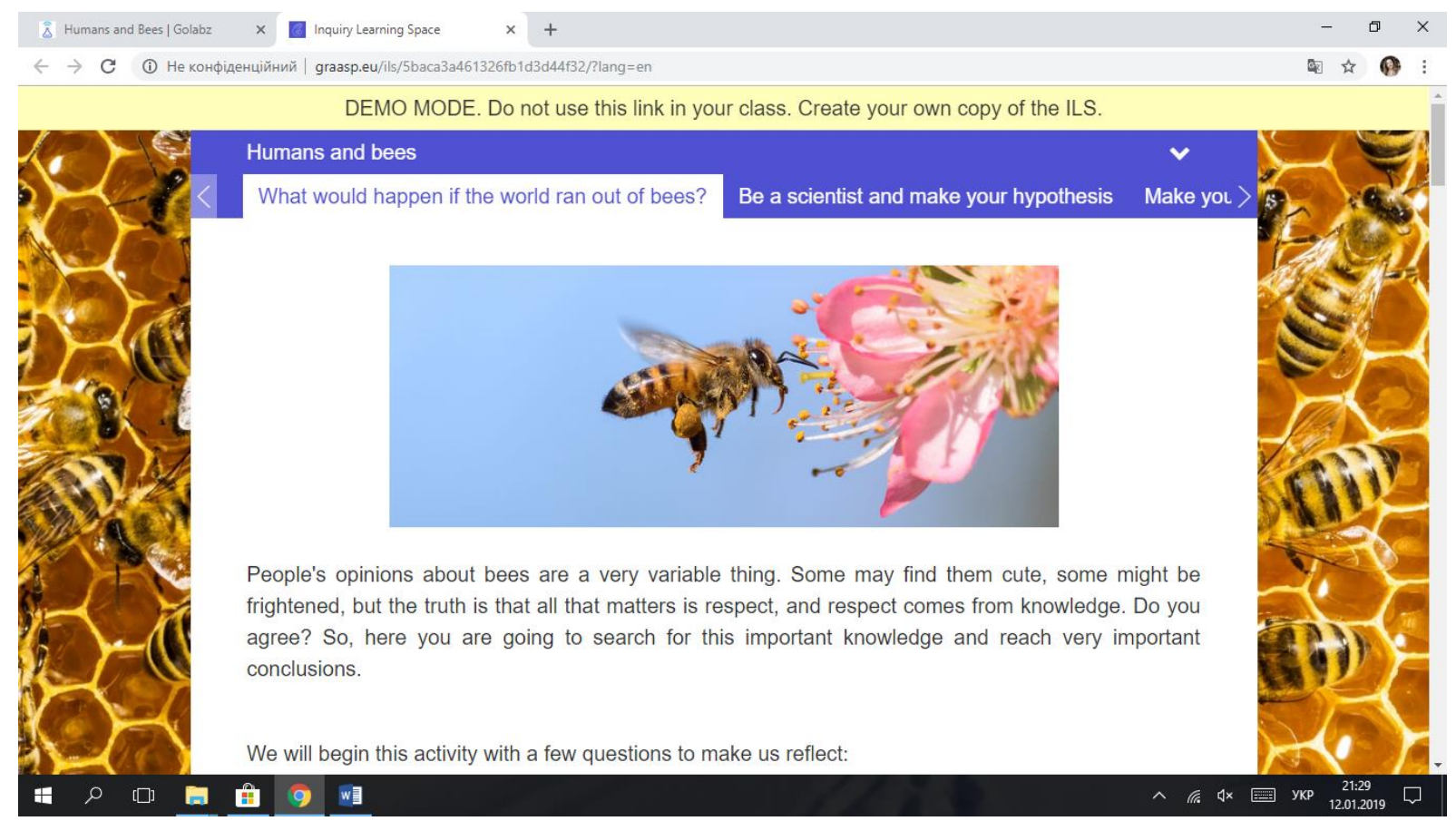

Fig. 1a. ILS "Humans and Bees" (Phase: What would happen if the world ran out of bees?).

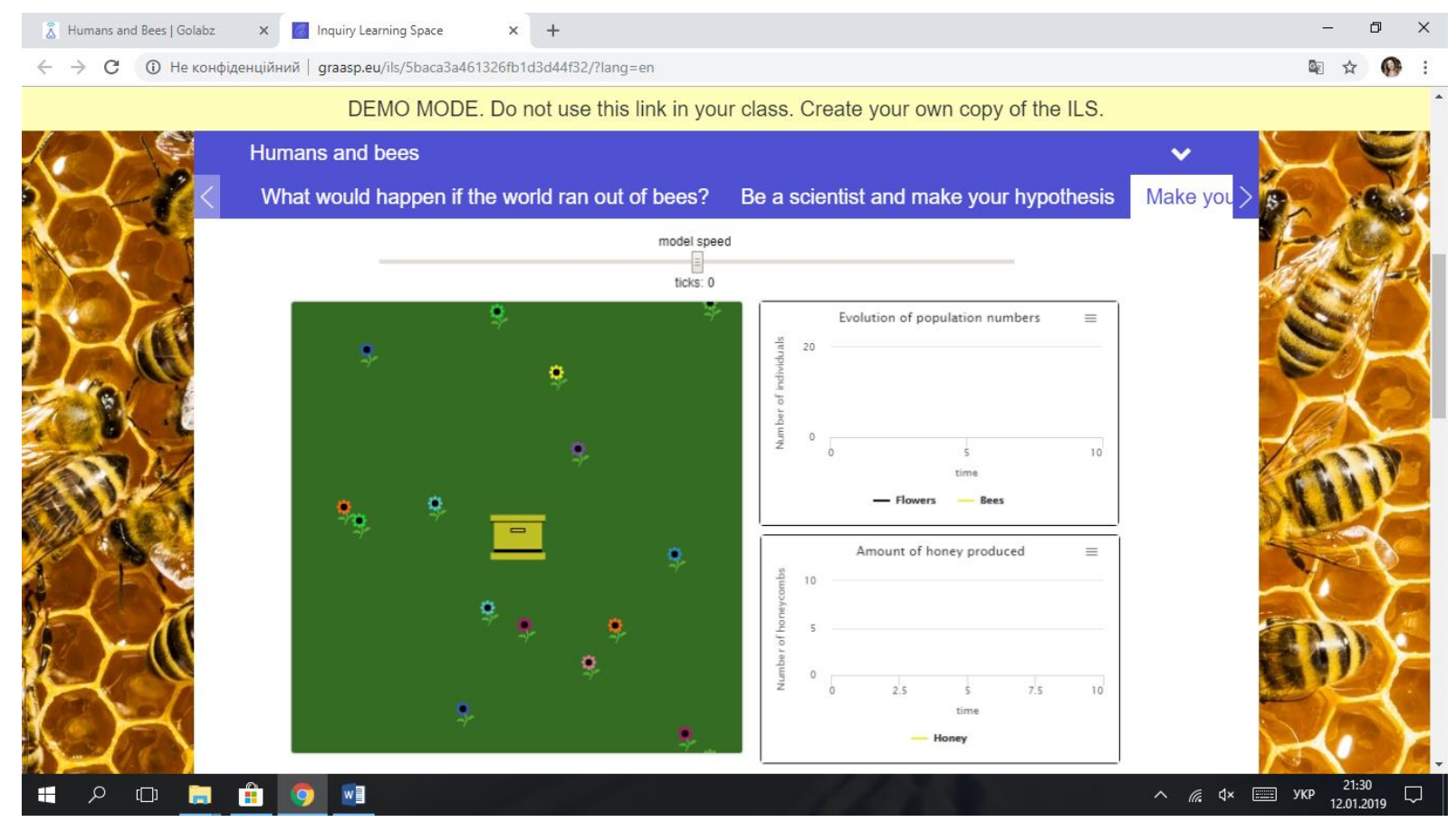

Fig. 1b. ILS "Humans and Bees" (Phase: Make your experiments and get results).

After the presented research, the students independently come to some conclusions, use tools to check if their hypotheses were valid at the beginning of working with this learning environment.

It is very important that, in the process of using this method of teaching, the students are encouraged to project work in groups or pairs, since they must take advantage of the knowledge gained and think how to apply them in real life. To do this, use the Phase: Share with your class and discuss! - where they are offered the following task: "Now ... what do you think that humans could do to improve their behavior towards bees? Imagine that you were invited by the government to produce an awareness campaign to teach citizens about personal choices that could help protect the bees. What would you create? What advice would you give? Work with your group to create something like this and upload you work below" (http://graasp.eu/ils/5baca3a461326fb1d3d44f32/?lang=en). 
It is important that the ILS contains an extremely varied training material: online labs, problem questions, video clips, games, illustrations, rules, etc. Students work on their own according to the relevant instruction. At the same time, the teacher has the opportunity to see the results of each student (the time and quality of continuing their respective phases of training) with the help of platformspecific tools for evaluation.

The next ILS "Windmill with Science Journal" (Science Journal from Google has a windmill project where the technology and engineering of an Anduino One and a lightsensor are helping to understand how the windmill works, https://www.golabz.eu/ils/windmill-with-science-journal-google) for students aged 13 and older (Fig. 2).

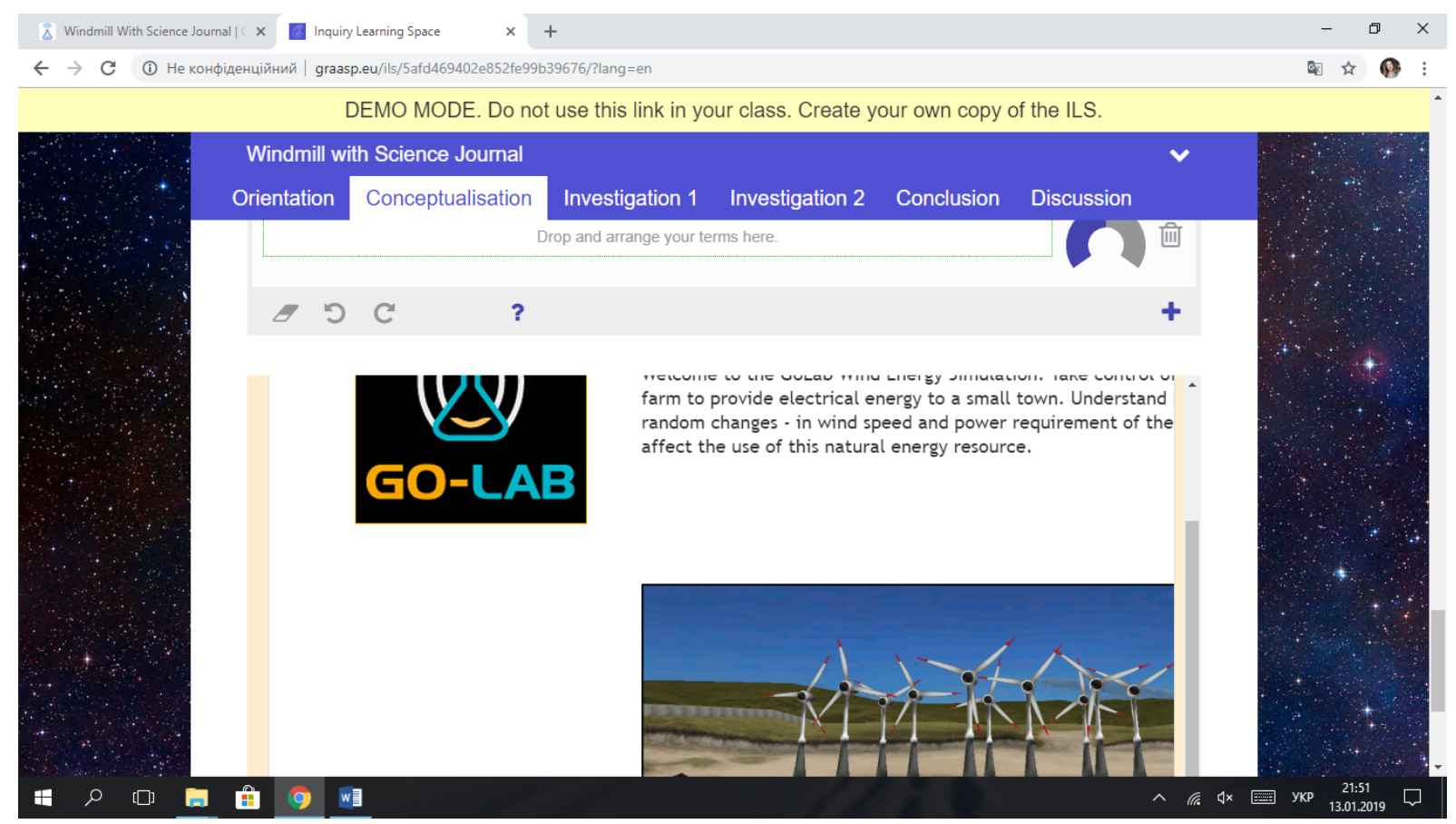

Fig. 2a. ILS "Windmill With Science Journal" (Phase: Conceptualisation).

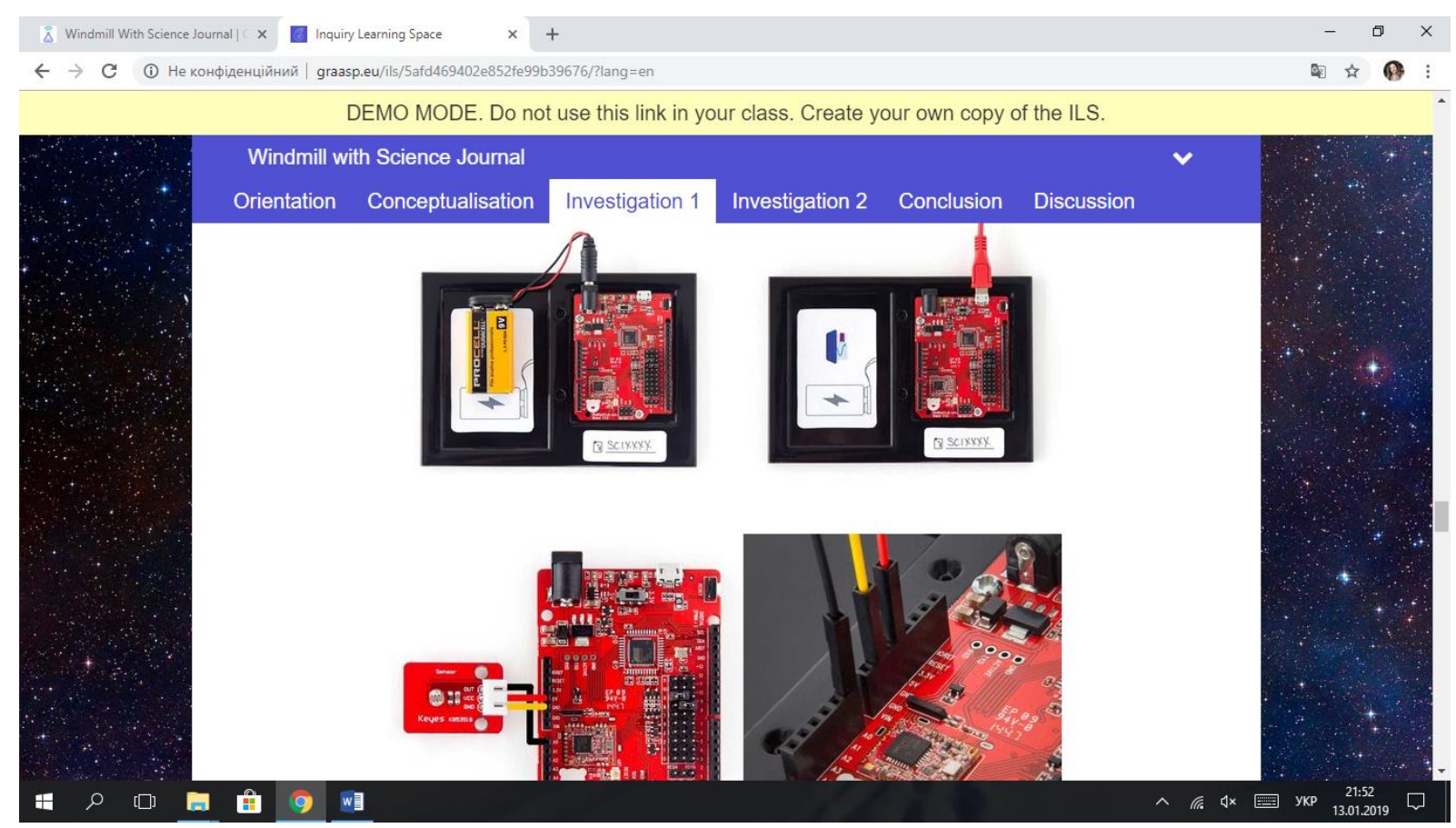

Fig. 2b. ILS "Windmill With Science Journal" (Phase: Investigation 1). 
Students have the opportunity to learn, that "windmills usually were used to mill grain, pump water or both... Modern windmills take the form of wind turbines used to generate electricity, or windpumps used to pump water, either for land drainage or to extract groundwater" (http:/graasp.eu/ils/5afd469402e852fe99b39676/?lang=en). In the "Conceptualization" section, they get the task of making a Concept Map about the windmill, and also create their hypotheses. For this useful questions are: How can you determine the number of blades that your windmill will need to spin at top speed? How efficient is a wind mill?

The pedagogical value of this type of learning is that students receive practical knowledge that is related to life. Example, in GoLab Wind Energy Simulation they will be able to solve "problems" that will require a critical comprehension of the material, the integration of knowledge on various subjects: Engineering, Mathematics, Physics, Technology, Computer Science, Architecture, Design, etc. To do this, they get the following tasks: "Take control of a wind farm to provide electrical energy to a small town. Understand how random changes - in wind speed and power requirement of the town - affect the use of this natural energy resource"; "Learn about the concept of efficiency as it relates to power generation at a wind turbine using our interactive simulation", etc.

At the same time the students can experiment and among them are the following: to create a windmill, to test it, to analyze the principle of its action and applied application, etc.

To solve research tasks, the student needs certain skills of logical and creative thinking. In the process of research teaching the teacher aims to form students the skills that are the basis of their research behavior. It is the ability to determine the problem, ask questions and answer them, put forward and review the hypotheses, explain the nature of scientific concepts and give them the definition, classify the material, observe, conduct experiments, draw conclusions, discuss educational problems, convincingly defend their opinions, etc.

ILS is also interesting because of "Curved Mirrors" for the pupils at the age of 13-14 years old (Physics,_https://www.golabz.eu/ils/curved-mirrors) (Fig. 3). This ILS is used in the Form 2 (grade 10) Kenyan curriculum. The learners at this stage have already been taught about the rectilinear propagation of light.

The objectives of this lesson is that by the end of the lesson the learners will be able to:

(1) determine experimentally the characteristics of images formed by a concave mirror;

(2) determine magnification for the images;

(3) plot graphs that can be used to determine the focal length of a concave mirror.

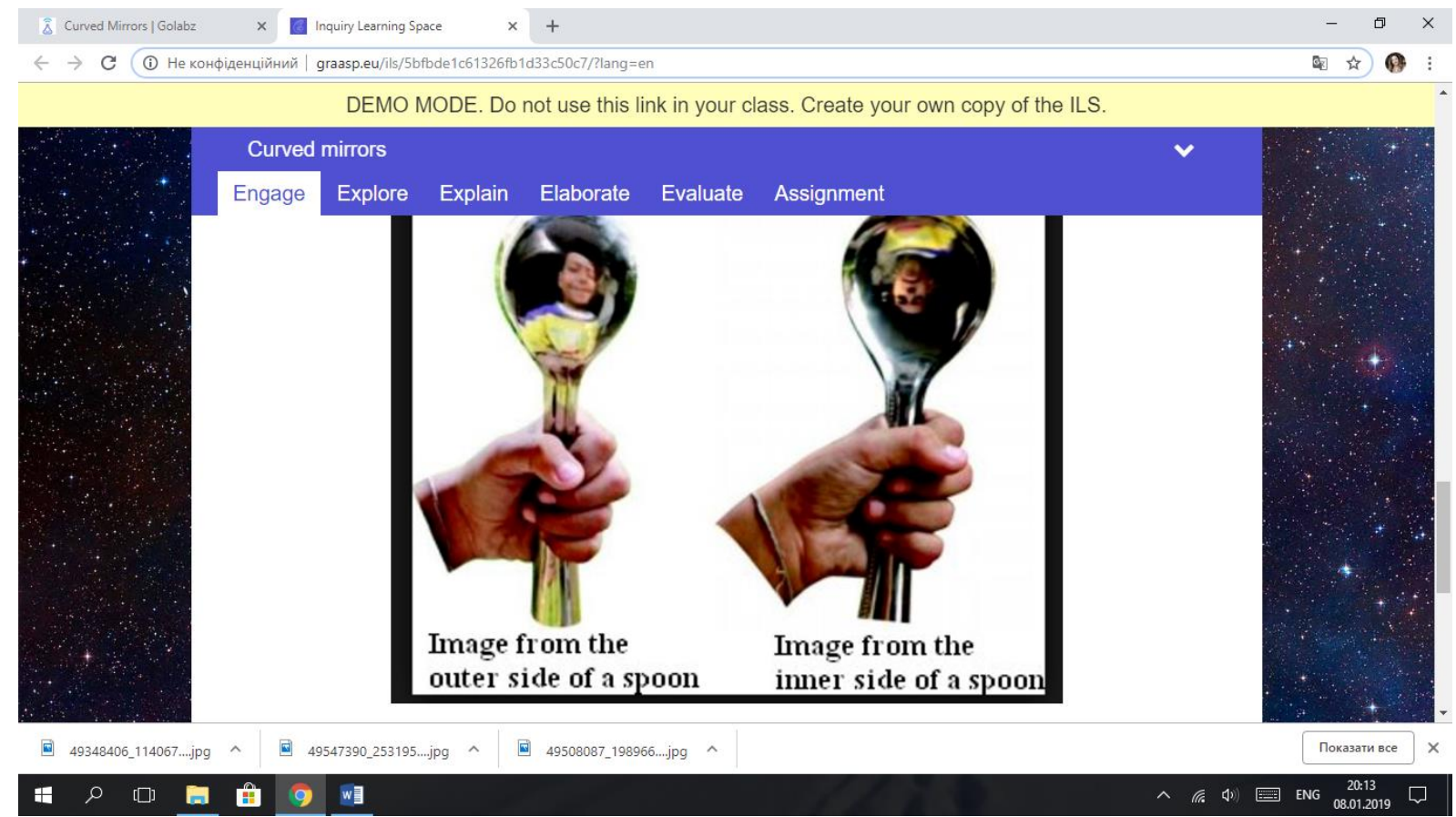

Fig. 3. ILS "Curved Mirrors". 
For teachers of astronomy is proposed 25 ILS for using: "Travelling To Mars" (https://www.golabz. eu/ils/travelling-to-mars) (In this activity students will work on trajectories by trying to send a spacecraft to Mars. Since Earth and Mars are in constant motion students also get acquainted with the notion of relative motion), "Craters in the Solar System" (https://www.golabz.eu/ils/craters-in-thesolar-system) (The lesson use the Impact Calculator lab to investigate what happens when a comet or asteroid hits a solar body. It explains the formation of craters in the entire solar system), "Interstellar The Mystery of Nebulae" (https://www.golabz.eu/ils/interstellar-the-mystery-of-nebulae), where the pupils have an opportunity to find the answer to the question: What is a Star? How is a Star born? Have you ever wondered what happens to the different stars in the night sky as they get older? And other.

For example, during the using of ILS "Explore the Sun" (https://www.golabz.eu/ils/explore-the-sun) the students will have the chance to explore the Sun's activity through the measuring of the size and counting of the number of Its Sun spots (Fig. 4).

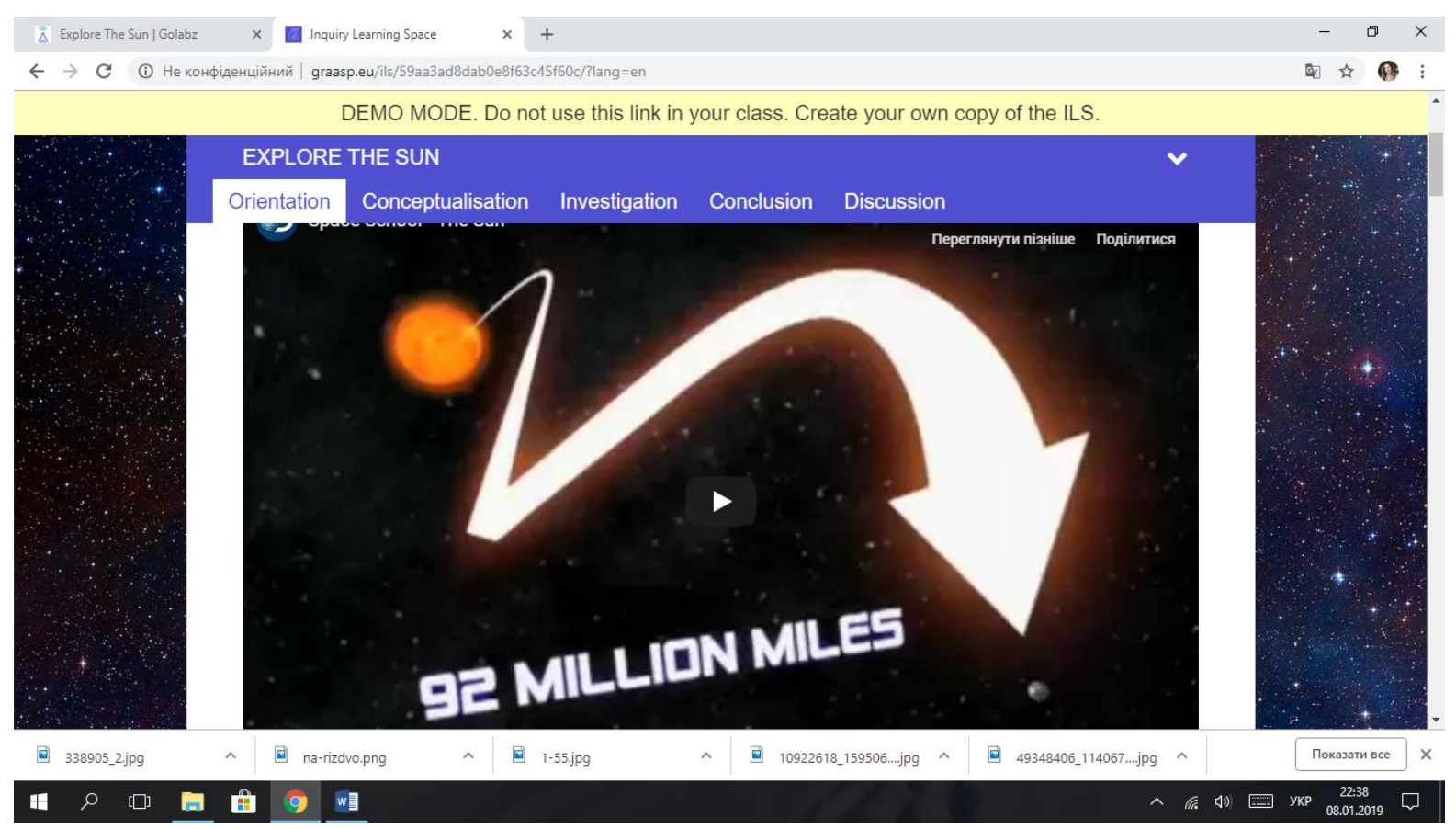

Fig. 4a. ILS "Explore The Sun" (Phase: Orientation).
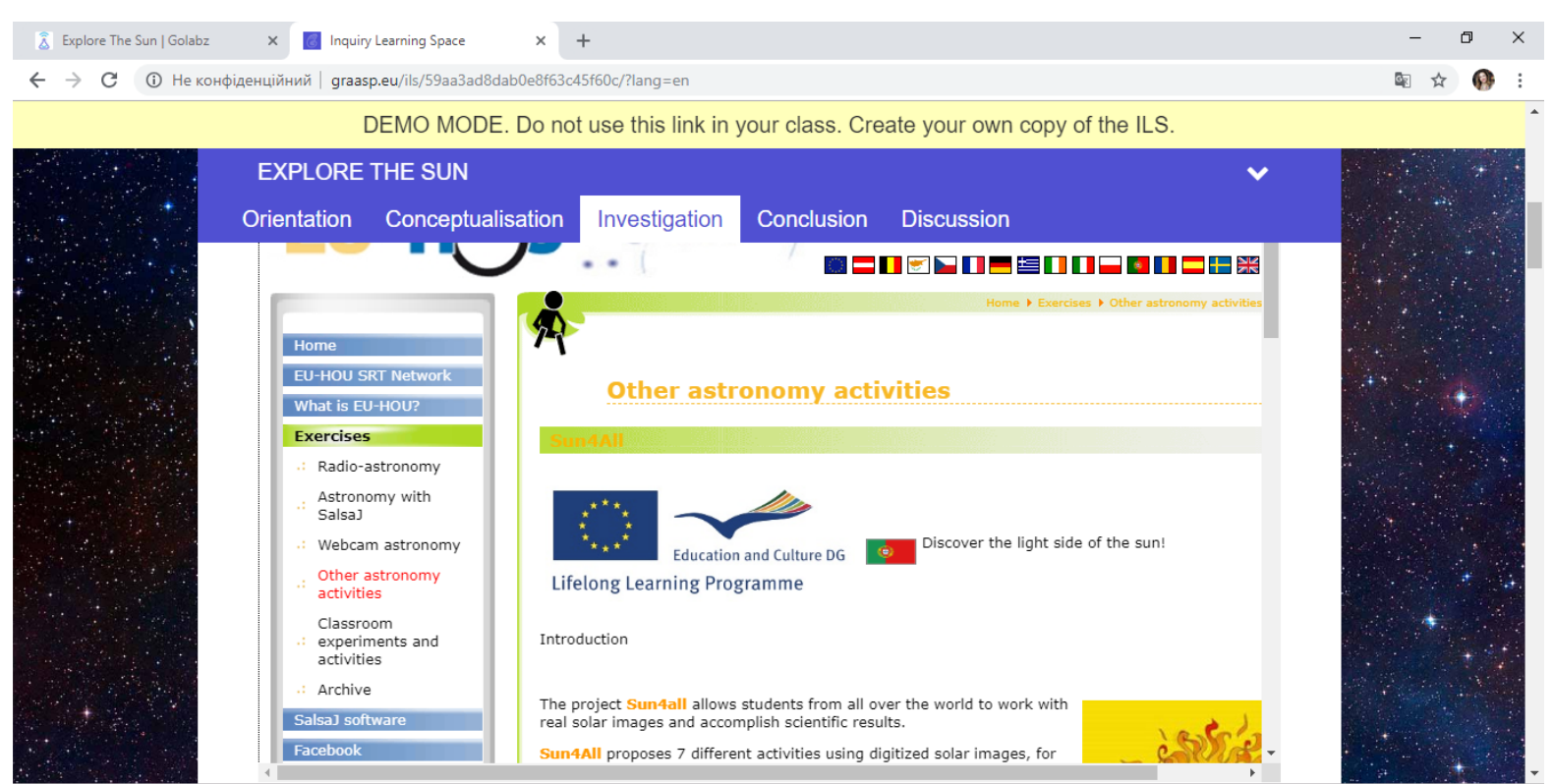

Other astronomy activities

(338905_2.jpg

The project Sun4all allows students from all over
real solar images and accomplish scientific results.

Sun4All proposes 7 different activities using digitized solar images, for

na-rizdvo.png

回 $1-55 . j p g$

回 10922618_159506....jpg

回 49348406_114067....jpg

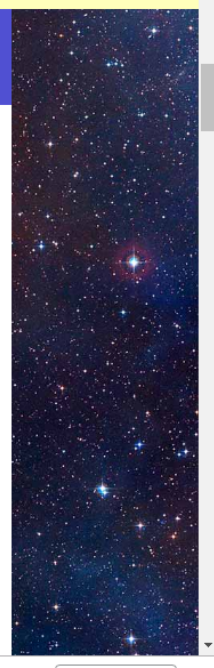

Показати все $\times$

* $\rho$ 回

Fig. 4b. ILS "Explore The Sun" (Phase: Investigation). 
After a general acquaintance of the students with the problem, they proceed to the next stage of "Conceptualization". Here they are offered research questions: What is solar activity? How Galileo Galilei discover sunspots? Is we can use directly telescope to made observation of sunspots? How many are the sunspots Image? How we can made explorations of solar activity? How we can discover is there are solar activity? And other. To address these issues, you need to go to the "Investigation" stage, then make "Conclusion" and discuss the results in the "Discussion" section.

So, "inquiry requires students to engage in active learning by generating their own driving questions, seeking out answers, and exploring complex problems. Research, though often a component of inquiry, addresses the process of finding answers" [13].

The educational platform GO-LAB is very popular for many countries, therefore, lecturers and undergraduate students of Precarpathian National University are actively working on creating these learning environments in Ukrainian language. It will give an opportunity for the teachers of secondary schools to offer new qualitative tools for teaching (learning) STEAM subjects.

However, in contrast with the traditional learning, where the students during the lessons can gain the learned facts, ILS encourages students to think, solve a difficult situation on their own way, find the answers to questions, and formulate a hypothesis. It helps the students learn through their own investigation. "While research can certainly exist as a stand-alone process, inquiry should ultimately drive students to view research as a means through which they can seek out new ideas, answer new questions, and wrestle with complex problems" [13].

It is important that the elements of online learning enable independent work of students to master or consolidate the teaching material in a convenient place for them, the necessary pace, at any time, etc.

\subsection{InTEgration of Educational Subjects in the School: Project Based Learning}

In the New Ukrainian school, the leading principle of its activity the integrated learning is determined as a guiding principle of its activities as one of the ways in which students can create a coherent picture of the world. The interdisciplinary approach is a specific feature of modern education in leading foreign countries (Europe, Singapore, Finland, Canada, Germany, etc.). The reforming the Ukrainian education system involves "overcoming the isolated teaching of subjects, educational themes and problems and creating fundamentally new educational programs where the educational process should be oriented towards a developmental and productive approach towards the development of integrated textbooks, the introduction of integrated courses, the implementation of integrated lessons and the use of integrated systems educational tasks" [15, p. 6].

Integrated study of students in a general secondary education establishment does not mean the rejection of individual subjects: each lesson must address the many-sided aspects of the knowledge of the world, ways to self-search for methods for expanding this knowledge. At the same time, an integrated approach to learning contributes to expanding the social and cognitive experience of students in the process of solving their problem situations in the context of interdisciplinarity.

One of the effective methods for implementing integrated lessons is the project method.

"When confronted with a challenging problem or question, students ask questions, find resources to help answer them, then ask deeper questions - and the process repeats until a satisfactory solution or answer is developed. Projects can incorporate different information sources, mixing the traditional idea of "research" - reading a book or searching a website - with more real-world, field-based interviews with experts, service providers and users" [10].

However, there are some difficulties in the using of Project Based Learning (PBL), and it concerns first of all of multidisciplinary projects. It is very often that projects are not well-prepared, their tasks are not clear for students, teachers spend a lot of time, but the results are upset. Project training should be focused, first of all, at building key skills for life. Its main elements should be clearly planned in accordance with the requirements of pedagogical design.

"Gold Standard PBL teaches students the important content standards, concepts, and in-depth understandings that are fundamental to school subject areas and academic disciplines. In good projects, 
students learn how to apply knowledge to the real world, and use it to solve problems, answer complex questions, and create high-quality products" [10].

In modern conditions, there is a tendency when the teachers and students not always show the wish or are interested to work on the integrated teaching methodology. Therefore, there is the notion of "disciplinary egocentrism" [22]. "Disciplinary egocentrism encompasses two factors, a negative relatedness and a negative perspective. The first one is a failure to see connections between a given discipline and an interdisciplinary subject or problem, which limits the ability to incorporate new ideas and practices. The second aspect is not only a rejection of other viewpoints, but often a failure to recognize the differences in perspectives and contributions. It is quite likely that disciplinary egocentrism is as much present in academic staff as a student body and that this may be a factor in the slow adoption of new pedagogies in any discipline" [8].

Foreign practice certifies the effectiveness of integrated training also in university education. Andy M. Connor, Sangeeta Karmokar, and Chris Whittington (2015) emphasize that "the tenets of the STEAM movement can be adopted in tertiary education where modularization and semesterization can produce barriers to an integrative curriculum" [8, p. 37]. The idea of teaching students with the application of interdisciplinary and applied methods is popular. It is no coincidence that many modern researches are devoted to this problem [8], especially the using of project methodology in the study of integrated courses in engineering education.

The authors define three types of projects that differ in the degree of student autonomy:

1. Task project: Student teams work on the projects that have been defined by the instructor using largely instructor-prescribed methods. This type of project provides for minimal student motivation and skill development, and is part of the traditional instruction in most engineering curriculum.

2. Discipline project: The instructor defines the subject area of the projects and specifies in general terms the approaches to be used (which usually involve methods common in the subject area discipline), but students identify the specific project and design the particular the approach they will take to complete it.

3. Problem project: The students have almost complete autonomy to choose their project and their approach to it [8, p. 38].

We consider it reasonable to use this method in teaching teachers to teach STEAM subjects in a secondary school. It is important to involve students in cooperative learning, teamwork, where they can share their thoughts, apply new knowledge for a deeper understanding of the problem [19].

Therefore, an effective form of on-line learning is the student's project activity. In particular, "mini projects were found to be one of the most effective strategies to complete the final project. Mini projects allow students time to master specific concepts and skills, such as checking initial data and forming a research question while internalizing learning" [23]. Actually, mini project helps in the real using of gained knowledge and its integral representation.

Thus, the method of projects causes the formation of such skills: critical thinking/problem solving, collaboration, and self-management. Projects may help build other skills, habits of mind and work, and personal qualities (such as perseverance or creativity), based on what teachers, schools, parents and communities value, but we argue that the ability to think critically, solve problems, work with others and manage oneself and one's own work are crucial stepping stones to future success [10].

\section{CONCLUSIONS}

Innovative competence of modern educator is manifested in the ability to timely react on changes, which takes place in the educational sector and implement innovative technologies in school practice. This will not only increase the effectiveness of learning / teaching, but also will give an opportunity to spread the educational abilities of students, personalize learning, transform the style and image of the teacher. We believe that the current school education reform needs the training of a new teacher who thinks innovatively, who can use digital technologies in working with students who are not afraid to experiment with pedagogical activity. However, move from the traditional learning to innovation, 
which encourages the student to analyze and interpret information; ask new questions; create work theories and generate scientific ideas, needs professional teacher skills.

Thus, in the conditions of the rapid development of the information society, the necessity of forming an innovative and modern teacher. Undoubtedly, the using of ICTs and educational innovations (Inquiry Based Learning, Project Based Learning, Blended Learning, Problem Based Learning, etc.) and there performs an interactive interaction between the teacher and students and spread the teaching and educational and scientific and research opportunities of education graduates. This opportunity in some cases stimulates the formation and development of the necessary system of key competencies, the ability to solve various professional tasks.

\section{REFERENCES}

[1] Armitage A., Pihl O., Ryberg T. PBL and Creative Processes. Journal of Problem Based Learning in Higher Education, 3 (1) (2015): Special Issue: PBL and Creative Processes, I-IV. doi: https://journals.aau.dk/index.php/pbl/article/view/1199

[2] Blended Learning. The Clayton Christensen Institute. Available at: https://www.christenseninstitute.org/key-concepts/blended-learning/

[3] Bykov V.Yu. Distance learning. In: Kremen V.G. (Ed.) Encyclopedia of Education of Ukraine. Yurinkom Inter, Kyiv, 2008, 191-193. (in Ukrainian)

[4] Budnyk O. Professional Training of Primary School Teachers to Social and Educational Activities: Theory and Practice. "Seredniak T.K.", Dnipropetrovsk, 2014. (in Ukrainian)

[5] Budnyk O. Theoretical principles of using STEAM-technologies in the preparation of the teacher of the New Ukrainian School. Journal of Vasyl Stefanyk Precarpathian National University, 5 (1) (2018), 23-30. doi: 10.15330/jpnu.5.1.23-30

[6] Budnyk O. The use of Blended Learning Methods in a Higher Education Institution. Obrii, 1 (46) (2018), 4-11. (in Ukrainian)

[7] Cairns D. R., Curtis R., Sierros K.A., \& Bolyard J.J. Taking Professional Development From 2D to 3D: Design-Based Learning, 2D Modeling, and 3D Fabrication for Authentic Standards-Aligned Lesson Plans. The Interdisciplinary Journal of Problem-Based Learning, 12 (2) (2018). Available at: https://docs.lib.purdue.edu/ijpbl/vol12/iss2/8/

[8] Connor A.M., Karmokar S., Whittington C. From STEM to STEAM: Strategies for Enhancing Engineering \& Technology Education. International Journal of Engineering Pedagogy, 5 (2) (2015), 37-47.

[9] Dychkivska I.M. Innovative pedagogical technologies. Akademvydav, Kyiv, 2012. (in Ukrainian)

[10] Gold Standard PBL: Essential Project Design Elements. Adapted from Setting the Standard for Project Based Learning: A Proven Approach to Rigorous Classroom Instruction, by John Larmer, John Mergendoller, Suzie Boss (ASCD 2015). Available at: https://www.pblworks.org/blog/gold-standardpbl-essential-project-design-elements

[11] Graham C.R. Blended learning system: Definition, current trends and future direction. In: Bonk C.J., Graham C.R. (Eds.) Handbook of Blended Learning: Global Perspectives, Local Designs. Pfeiffer, San Francisco, 2005, 3-21.

[12] Havrysh I.V. The regularities and principles of the process of forming the readiness of future teachers for innovative professional activities. In: The reality and perspectives for the Development of modern education in Ukraine. Styl-Izdat, Kharkiv, 2005, 61-74. (in Ukrainian)

[13] Holland B. Inquiry and the Research Process: Tips for ensuring that your students' research fosters genuine inquiry, (2017). Available at: https://www.edutopia.org/article/inquiry-and-research-process

[14] Hofmann J. Top 10 Challenges of Blended Learning. Training, march/april (2011). Available at: http://ww.w.cedma-

europe.org/newsletter\%20articles/Training\%20Magazine/Top\%2010\%20Challenges\%20of\%20Blended\% 20Learning\%20(Apr\%2011).pdf 
[15] Dobrovolska L.N., Chornovil V.O. (Eds.) The integration of educational subjects in elementary school as an effective form of training for junior pupils, materials of an online seminar. Publishing house CEE "Cherkasy Regional Institute of Postgraduate Education of Teachers of Cherkasy Regional Council", Cherkasy, 2017. (in Ukrainian)

[16] Klepko S. Integration and polyformism of knowledge in higher education. Philosophy of Education, 2 (2) (2005), 20-34. (in Ukrainian)

[17] Krayevskiy V. Upbringing or Education? Pedagogy, 3 (2001), 3-10. (in Russian)

[18] Massachusetts Creativity \& Innovation Initiative. Curriculum Design Projects, 2014-2015 Fund Code 189. Available at: http://www.doe.mass.edu/ccr/initiatives/CreativityBooklet.pdf

[19] Miller S.T, Redman S.L. Enhancing student performance in an online introductory astronomy course with video demonstrations. Astronomy Education Review, 9 (1) (2010). doi: 10.3847/AER2009072

[20] Petrychenko L. Theoretical and methodological principles of formation of innovative competence of future teachers of elementary school. Available at: http://vuzlib.com/content/view/343/84/ (in Ukrainian)

[21] Protsenko O., Yurochko S. Innovative competence of the teacher: content and structure. Molod $i$ rynok, 5 (124) (2015), 51-55. (in Ukrainian)

[22] Richter D.M., Paretti M.C. Identifying barriers to and outcomes of interdisciplinarity in the engineering classroom. European Journal of Engineering Education, 34 (1) (2009), 29-45. Available at: http://dx.doi.org/10.1080/03043790802710185

[23] Yang D. Instructional strategies and course design for teaching statistics online: perspectives from online students. International Journal of STEM Education, 4 (34) (2017). Available at: https://doi.org/10.1186/s40594-017-0096-x

[24] Yatsun O.M. The university faces the challenges of globalization: the social aspect. Higher Education of Ukraine. Thematic issue "European Integration of Higher Education in Ukraine in the Context of the Bologna Process", 1 (3) (2012), 104-106. (in Ukrainian)

[25] Ziaziun I.A. Philosophy of Pedagogical Action: monograph. Publishing House. Bogdan Khmelnitsky ChNU, Cherkasy, 2008. (in Ukrainian)

Address: Olena Budnyk, Vasyl Stefanyk Precarpathian National University, 57, Shevchenko Str., IvanoFrankivsk, 76018, Ukraine.

E-mail: olena.budnyk@pu.if.ua

Received: 15.01.2019; revised: 27.03.2019.

Будник Олена. Інноваційна компетентність педагога: кращі європейські практики. Журнал Прикарпатського університету імені Василя Стефаника, 6 (1) (2019), 76-89.

У статті обгрунтовано сутність інноваційної компетентності педагога в руслі інтегрування до світового простору освіти. Охарактеризовано основні закономірності підготовки вчитедя до професійної інноваційної діяльності. Охарактеризовано кращі європейські практики щодо використання новітніх технологій навчання в роботі 3 учнями (студентами). Автор доводить необхідність організації партнерської взаємодії, групових видів діяльності у вирішенні проблемних пізнавальних завдань у школі з допомогою проблемного навчання; зокрема, висвітлено питання розвитку творчої ініціативи дітей у колективній роботі. Описано зміст і типові труднощі у практичному використанні методики змішаного навчання. Зазначено, що в змішаному навчанні органічно поєднуються традиційна та дистанційна моделі навчання; воно відбувається в аудиторії та поза іiі межами, у синхронному чи асинхронному режимах, передбачає широке використання IКТ в освітньому процесі. Представлено технологію дослідницького навчання (IBL) шкільних предметів STEAM (зокрема, у роботі з віддаленими освітніми лабораторіями), а також дослідницьких 
навчальних середовищ онлайн (ILS). Приведено деякі інноваційні інструменти щодо їх практичного використання в роботі з учнями. Обгрунтовано також важдивість використання методу проектів для інтегрування навчальних предметів у Новій українській школі, що дає мождивість формувати цілісну картину світу в здобувачів освіти.

Ключові слова: інноваційна компетентність педагога, освітній процес, педагогічна діяльність, проблемне навчання, змішане навчання, проектне навчання, дослідницьке навчання.
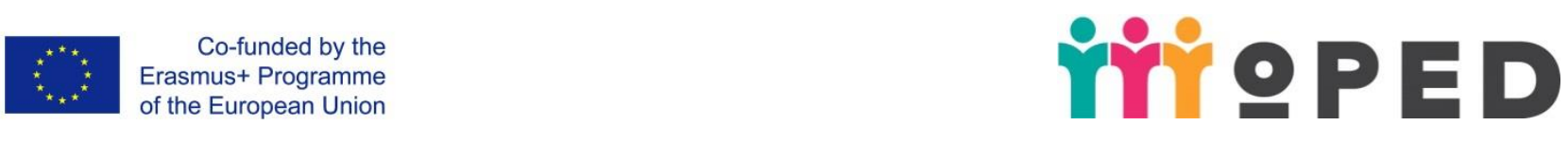

"The article has been prepared in the framework of the Erasmus+ project "MoPED - Modernization of Pedagogical Higher Education by Innovative Teaching Instruments", No. 586098-EPP-1-2017-1-UAEPPKA2-CBHE-JP. This project has been funded with support from the European Commission. This publication reflects the views only of the author, and the Commission cannot be held responsible for any use which may be made of the information contained therein". 